\title{
Strategi Bersaing Perguruan Tinggi Menghadapi Liberalisasi Pendidikan
}

\author{
M.Suyanto
}

\begin{abstract}
The liberalization of education will be equal to the liberalization of economy because it implies on the investors profit of international of education. The entering of foreign universities will increase the competitive advantage of Indonesian universities. The competitive strategy is very rigid that causes the bloody ocean for those universities. This strategy will be called Bloody or Red Ocean Strategy. To avoid this rigid competitive, there are three effective mutual effects: focus, move to avoid, and main motto. Besides, there are the relation between analysis techniques and six principles in formulating and applying the Blue Ocean Strategy will make the universities in Indonesia survive.
\end{abstract}

Kata Kunci: bersaing, liberalisasi, perguruan tinggi, dan strategi

1 iberalisme dikemukan pertama kali oleh Alexander Rustow dan Walter Eucken padaa awal.1930-an. Liberalisme menganjurkan penyelenggaraan ekonomi pasar bebas dan negara berfungsi untuk memfasilitasi pasar bebas tersebut dengan membuat undangundang atau peraturan. Gagasan Rustow dan Eucken tersebut dikembangkan oleh Wilhelm Ropke dan Henry C. Simon.

Freiburger membuat paket kebijakan ekonomi yang dikenal sebagai paket kebijakan Ordoliberalisme. Kebijakan ini sesungguhnya kebijakan ekonomi liberal model baru (neoliberal). Garis kebijakan ini menyangkut: (1) pengembangan kebebasan individu untuk bersaing secara bebassempurna di pasar, (2) kepemilikan pribadi terhadap faktor-faktor produksi diakui, (3) pembentukan harga pasar bukanlah sesuatu yang alami, melainkan hasil dari penertiban pasar yang dilakukan oleh negara melalui penertiban undang-undang.
Pada akhir 1970-an, tejadi depresi besar menyebabkan ekonomi neoliberal tersisih dengan munculnya ekonomi negara kesejahteraan yang dikemukakan oleh Maynard Keynes. Konsep negara kesejahteraan, peranan negara dalam bidang ekonomi tidak dibatasi hanya sebagapembuat peraturaturan, tetapi diperluas sehingga meliputi pula kewenangan untuk melakukan intervensi fiskal, khususnya untukmenggerakkan sektor riil dan menciptakkan lapangan keja.

Setelah terpilihnya Ronald Reagan sebagai presiden Amerika Serikat dan Margareth Teatcher sebagi perdana menteri Inggris pada awal 1980-an, gagasan ekonomi neoliberal disempurnakan oleh Milton Friedman dan disebarluaskan ke seluruh dunia, terutama pada saat terjadinya krisis di Amerika Latin di penghujung 1980an. Untuk mengatasi krisis tersebut Amerika Latin bekerjasama dengan departemen Keuangan Amerika Serikat dan IMF meluncurkan kebijakan ekonomi yang dikenal kebijakan Konsensus Washington. Kebijakan Konsesus Washington meliputi 
empat hal, yaitu (1) pelaksaanaan kebijakan anggaran ketat, termasuk penghapusan subsidi negara dalam berbagai bentuknya, (2) pelaksanaan liberalisasi sektor keuangan, (3) pelaksanaan liberalisasi sektor perdagangan dan (4) pelaksanaan privatisasi BUMN. Dampaknya liberasi ekonomi pada negara miskin seperti Indonesia terletak pada melemahnya kemampuan sebuah ketergantungan perekonomian negara-negara miskin tersebut terhadap pemenuhan kepentingan para pemodal internasional yang berasal dari negara-negara kaya tertentu. Dalam ungkapan teori ketergantungan, sebagai akibat dari globalisasi, maka perekonomian negara-negara miskin cenderung menjadi wilayah pinggiran bagi perekonomian negara-negara kaya. Akibat meningkatnya ketergantungan ekonomi negara-negara miskin terhadap pemenuhan kepentingan para pemodal yang berasal dari negaranegara kaya, maka peranan pemerintah dalam perekonomian negara-negara miskin cenderung mengalami perubahan fungsi, yaitu melayani dan melindungi kepentingan rakyat menjadi melayani dan melindungi kepentingan para pemodal internasional yang ingin atau telah menanamkan modal mereka di negara-negara yang bersangkutan. Pada tingkat yang paling ekstrim, kebijakan ekonomi pemerintah negara-negara miskin justru secara terangterangan mengambil posisi berlawanan dengan aspirasi rakyat mereka sendiri.

Menurut Sri Edi Swasono, globalisasi dan pasar-bebas memang dimajinasikan sebagai upaya meningkatkan efisiensi global. Saat ini imajinasi dan upaya itu ditumpahkan kepada organisasi dunia WTO, yang mematok pakem-pakem ekonomi pasar bebas untuk mencapai efisiensi global. Namun dari kenyataan empirik yang ada, membuat banyak diantara kita harus bersikap menolak dan reaksioner. Berdasarkan data dari OCdab IBR(1992), perdagangan Masyarakat Ekonomi Eropa surplus $\$ 80700$ juta, USA surplus $\$ 18800$ juta, Jepang surplus $\$ 25900$ juta, tetapi sebaliknya Afrika Selatan défisit $\$ 400$ juta, Negeria défisit $\$ 1000$ juta dan Indonesia défisit $\$ 1900$ juta. Terbukti memang yang menikmati liberalisasi hanyalah negaranegara.yang kaya.

Liberalisasi pendidikan akan mengalami nasib yang sama dengan liberalisasi ekonomi, tetap saja yang lebih beruntung adalah pemilik modal (pendidikan) internasional. WTO membungkusnya dengan dalih bahwa perguruan tinggi asing dapat memacu peningkatan mutu pendidikan Indonesia. Termasuk dapat meningkatkan akuntabilitas penyelenggaraan pendidikan, memperbaiki efisiensi pengelolaan pendidikan, serta mengurangi aliran uang ke luar negeri. Saya mengkhawatirkan yang dimaksud mutu adalah yang berkualitas dan berkepribadian seorang penganutliberalisme, yang jelas-jelas lebih memihak kepada pemilik modal, bukan memihak kepada rakyat.

Subsidi sebagai instrumen transfer kas darinegara kepada masyarakat, dapat dipakai untuk mendorong pemenuhan kebutuhan dasar masyarakat, untuk membantu kelompok masyarakat yang rentan, dan untuk meredistribusikan hasil produksi nasional dari sektor privat ke sektor publik. Redistribusi hasil produksi nasional dari sektor privat ke sektor publik ini sangat penting untuk membángun fondasi integrasi sosial di tengah-tengah masyarakat. Dengan demikian, dengan dilakukannya penghapusan subšidi dalam bidang pendidikan, hal itu tidak hanya akan menyebabkan semakin terabaikannya pemenuhan kebutuhan dasar masyarakat dan terpinggirkannya kelompokmasyarakat rentan, tindakan tersebut sekaligus akan menyebabkan terjadinya transformasi 
sejumlah kegiatan yang semula berada di sektor publik ke sektor publik itu, dapat dipastikan akan mendorong dilakukannya seleksi ulang terhadap siapa, mendapat apa dan berapa banyak di tengah-tengah masyarakat. Tindakan tersebut jelas merupakan ancaman sangat serius terhadap fondasi integrasi sosial yang dimiliki oleh masyarakat yang bersangkutan. Terbukti sekarang Perguruan Tinggi Negeri (BHMN) menarik biaya pendidikan cukup tinggi, yang dapat menyulitkan rakyat miskin. Bahkan biaya tersebut cukup menonjol pada pimpinan perguruan tinggi tersebut, bukan pada dosen dan karyawan bawah. Jarak gaji antara Pimpinan perguruan tinggi semakin jauh dengan karyawan dan dosen kelas bawah, hal ini menunjukkan kalau neoliberal telah memasuki perguruan tinggi yang telah menjadi BHMN.

Lebih dari itu, dikhawatirkan kasus Privatisasi BUMN, akan diikuti pula privatisasi BHMN (Badan Hukum Milik Negara) sebagaimana tercantum dalam Undangundang BUMN. Secara sederhana memang dapat diartikan sebagai penjualan sebagian atau seluruhnya saham BHMN dari tangan pemerintah kepada para pemodal swasta. Pengertian privatisasi yang sederhana tersebut tentu cenderung menyesatkan. Selain mengabaikan keterkaitan pelaksanaan privatisasi BHMN dengan pelaksanaan agenda-agenda ekonomi neoliberal yang lain, pengertian privatisasi yang sederhana itu juga cenderung mengabaikan dampak pelaksanaan privatisasi terhadap proses pemenuhan kebutuhan dasar rakyat akan pendidikan dan penguatan kemampuan sebuah negara dalam melindungi kedaulatannya.

Padahal, sebagaimana dikemukakan Petras dan Veltemeyer, dibandingkan dengan agenda-agenda ekonomi neoliberal yang lain, justru pelaksanaan kebijakan privatisasi BHMN inilah yang menjadi agenda utama pengembangan dan penyebarluasan neoliberalisme. Berbeda dari agenda-agenda ekonomi neoliberal yang lain, pelaksanaan privatisasi BHMN berkaitan secara langsung dengan proses pemindahan kepemilikan (tidak hanya kewenangan) faktor-faktor produksi, dari tangan Negara ke tangan para pemodal swasta.

Dengan kedudukan seperti itu, bahaya privatisasi $B H M N$, bagi negara-negara miskin dalam mencakup beberapa hal berikut: (1) privatisasi BHMN menyebabkan berkurangnya kemampuan sebuah negara untuk melindungi kepentingan negara dan rakyatnya dalam bidang pendidikan; (2) privatisasi menyebabkan semakin tergantungnya pemerintahan negaranegara miskin terhadap para pengaruh dan kekuasaan sektor swasta; dan (3) bila privatisasi dilakukan terhadap para pemilik modal internasional, maka privatisasi dapat merupakan jalan lurus menuju neokolonialisme (Baswir, 2003).

Dengandemikian, bilasecaraintemasional, liberalisasipendidikan cenderungmenyebabkan semakin meningkatnyaketergantungan Negaranegara miskin terhadapjaringan kekuatan modal yang dikendalikan oleh para pemodal yang berasal darinegara-negara kaya tertentu, maka secaradomestik hal tersebutœendenung menjadi pemicu porakporandanya fondasi intergrasisosial antara berbagai strata sosial dan ekonomi yang terdapatdalam masyarakat di masing-masing negara miskin yang bersangkutan. Dengan bahaya dan dampak negatif sebagaimana dipaparkan pada awal tulisan ini, mudah dimengerti bila Petras dan Veltmejer lebih suka menyebut liberalisme sebagai imperialisme. Sebagaimana ditegaskan, dibalik pengembangan dan penyebarluasan konsep globalisasi sesungguhnya bersemayam sebuah kepentingan kelas 
atas tertentu, yaitu kelas kapitalis internasional baru yang sedang berusaha melebarkan pengaruh dan dominasi ekonomi mereka ke seluruh penjuru dunia.

Sehubungan dengan itu, menjadi mudah dimengerti pula bila penyelenggaraan sidang Organisasi Perdagangan Dunia (WTO) di Cancun, Mexico, baru-baru ini, terpaksa dihentikan di tengah jalan dan gagal mencapai kesepakatan sebagaimana diharapkan. Penyebabnya adaiah mencuatnya perbedaan yang sangat besar antara kepentingan ekonomi Negara-negara kaya yang antara lain diwakili oleh AS dan Jepang, dengan kepentingan ekonomi Negara-negara miskin yang diwakili oleh Cina, India, Brasil dan Afrika Selatan, dalam mengatur tata perdagangan dunia secara berkeadilan (The Economist, edisi $20-26$ September 2003). Dengan demikian direncanakan penandatanganan perjanjian WTO dalam empat sektor, yaitu jasa profesional, jasa energi, jasa kesehatan, serta jasa pendidikan diadakan di Hongkong.

Tindakan apakah yang harus dilakukan oleh negara-negara miskin untuk mencegah berlanjutnya bahaya atau dampak negatif globalisasi terhadap masa depan Negara dan keutuhan bangsa mereka? Menerima liberalisasi pendidikan seperti apa adanya jelas bukan merupakan pilihan yang bijak. Demikian halnya dengan menolak liberalisasi pendidikan tanpa memberikan alternatif apapun. Menolak liberalisasi pendidikan tanpa memberikan alternatif sama saja dengan menyodorkan keputusan. Liberalisasi pendidikan ini akan memunculkan tiga aliran pemikiran sebagai berikut. Pertama, periawanan terhadap pelaksanaan agenda-agenda liberalisasi pendidikan. Dalam hal ini yang dipersoalkan terutama adalah soal waktu, sekuen, dan orang atau lembaga yang terkait dengan pelaksanaan agenda-agenda liberalisasi pendidikan. Prinsip dasar yang melatarbelakangi pelaksanaan agenda-agenda globalisasi cenderung tidak dipersoaikan atau diterima sebagaimana adanya.

Kedua, perlawanan terhadap agendaagenda liberalisasi pendidikan. Perlawanan terhadap liberlisasi pendidikan dalam bentuk kedua ini terutama diarahkan pada agendaagenda globalisasi tertentu secara spesifik. Karena diarahkan pada agenda-agenda liberalisasi pendidikan tertentu, maka perlawanan jenis yang kedua ini cenderung bersifat parsial. Sebagaimana aliran yang pertama, dalam aliran yang kedua ini, prinsip dasar yang melatarbelakangi liberlisasi pendidikan cenderung diterima apa adanya.

Ketiga, perlawanan terhadap neoliberalisme atau ideologi yang melatarbekalangi konsep liberalisasi pendidikan. Dalam bentukperlawanan yang ketiga ini, liberalisasi pendidikan langsung ditolak pada tingkat prinsipnya. Sayasendirilebih condong pada aliran yang ketiga. Prinsip dasar yang saya pakai sebagai titik tolak untukmenolak liberalisasi pendidikan adalah sebuah prinsip demokrasipendidikan. MenurutUUD1945, tiaptap warga berhak mendapat pengajaran dan pemerintah mengusahakan dan menyelenggarakan suatu sistem pengajaran nasional, yang diaturdengan Undang-undang.

Sebagaimana telah disinggung sebelumnya, keberhasilan Cina, India, Brazil dan Afrika Selatan dalam menghentikan arogansi negara-negara kaya dalam sidang WTO baru-baru ini, adalah sebuah momentum yang sangat tepat bagi negara-negara miskin untuk maju ke depan dengan prinsip dan agenda-agenda ekonomi dan pendidikan yang lebih sesuai dengan kepentingan negara dan mayoritas rakyat mereka sendiri. Untuk melanjutkan upaya-upaya serupa itu, para pemimpin negara-negara miskin tentu perlu membekali diri dengan kemauan politik yang kuat. Bersamaan dengan itu, mereka juga dituntut untuk terus merapatkan barisan 
Topik: Globalisasi dan Liberalisasi dalam Bidang Pendidikan

dan mempercepat hubungan antar sesama negara miskin se dunia.

\section{Strategi Bersaing Perguruan Tinggi dalam Liberalisasi Pendidikan}

Strategi bersaing pada persaingan yang sangat ketat dapat menimbulkan "lautan darah" bagi perguruan tinggi yang bersaing atau bertarung tersebut. Strategi.ini disebut sebagai Bloody or Red Ocean Strategy (strategi samudra merah). W. Chan Kim dan Renee Mauborgne (2005) menyatakan bahiwa Red Ocean Strategy sudah tidak lagi ampuh untuk menciptakan pertumbuhan dan keuntungan di masa depan. Mereka berdua mengusulkan sebuah strategi baru yang disebut 'Blue Ocean Strategy (strategi samudra biru).

Perbedaan antara Red Ocean Strategy dan Blue Ocean Strategy, antara lain dalam menyikapi tentang pasar, persaingan, permintaan, nilai dan strategi. Red Ocean Strategy menganggap bahwa bersaing itu adalah bersaing dalam ruang pasar yang ada, sedangkan Blue Ocean Strategy, menganggap bahwa bersaing adalah menciptakan ruang pasar yang tidak ada lawannya. Pasar yang sangat luas bagaiakan "lautan biru", dan perusahaan dapat memilih pasar sesuka hatinya. Red Ocean Strategy menggunakan konsep untuk dapat tumbuh dan mendapat keuntungan dengan mengalahkan pesaing dalam persaingan. Blue Ocean Strategy menggunakan konsep dengan membuat persaingan itu tidak ada, maka perusahaan hanya bersaing dengan dirinya sendiri tanpa perusahaan lain. Perusahaan tersebut pasti akan memenangkan persaingan tanpa lawan.

Red Ocean Strategy melakukan eksploitasi permintaan yang sudah ada habishabisan. Blue Ocean Strategy menciptakan dan menangkap permintaan baru. Red Ocean Strategy meraih keunggulan dengan menciptakan nilai, maka Blue Ocean Strategy meraih keunggulan dengan tanpa harus menciptakan nilai. Red Ocean Strategy bersatu dengan sistem secara keseluruhan dari aktivitas perusahaan dengan memilih strategi diferensiasi atau strategi kepemimpinan biaya keseluruhan (strategi biaya murah), sedangkan Blue Ocean Strategy bersatu dengan sistem secara keseluruhan dariaktivitas perusahaan dalam melaksanakan strategi diferensiasi dan strategi kepemimpinan biaya keseluruhan secara bersama-sama. Blue Ocean Strategy menyangkutduaaspek. Pertama, bagaimana menemukan dan mengembangkan blue ocean: Untukmenemukan dan mengembangkan blue ocean, dengan meluncurkan industri baru yang lengkap seperti eBay, melakukan lelang di internet dan melakukan yang lebih umum dengan memperluas batas industri yang diciptakan oleh red ocean. Kedua, bagaimana mengekploitasi dan melindungi blue ocean.

Kim dan Mauborgne (2005) memberikan contoh salah satu dari perusahaan yang diteliti adalah perusahaan Cirque du Soleil. Cirque telah melakukan pentas dengan menampilkan lusinan produksi yang dilihat oleh kira-kira 40 juta orang di 90 kota di sekeliling dunia. Dalam 20 tahun, Cirque telah mencapai pendapatan sirkus pemimpin dunia Ringling Bros dan Barnum \& Bailey. Kedua perusahaan sirkus pemimpin dunia tersebut untuk mencapainya dibutuhkan waktu 100 tahun.

Ringling Bros dan Barnum \& Bailey merancang sirkus standar dan bersaing dengan sirkus sejenis dalam skala pasar yang terus menurun. Ringling Bros dan Barnum \& Bailey menggunakan perspektif strategi berbasiskan persaingan, sehingga akhirnya industri sirkus yang muncul menjadi tidak menarik, sedangkan Cirque du Soleil's meraih sukses dengan tidak mengambil pasar dari industri sirkus yang 
ada; yang secara:historis pasarnya anak: anak. Cirque du Soleil tidak bersaing dengan. Ringling Bros dan Barnum \& Bailey; karena menciptakan pasar baruryang tidak:ada läwannyardan tmembuat persainganctidak: relevan lagi. Cirque du Soleil memuncúlkan pasar baru selain anak-anak adalah kelompok pelanggan baru orang dewasa dan klien perusahaan dengan tidak hanyá menampilkan sirkus, tetapi menampilkan teater opera dan balet sehingga penontonnya bersedia membayar beberapá kali lipat dibandingkan dengan sirkus tradisional biasa Strategi dari Cirque du solej inilah yang disebut Blue ocean strategy atau strategisamudra biru. Strategi inilan yang dapat diadaptasioleh perguruan tinggidalam persaingan yang sangat-ketat, $;$, w. J,

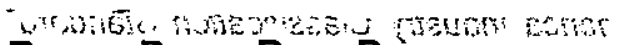

Ruang Pasar Baru, Perguruan

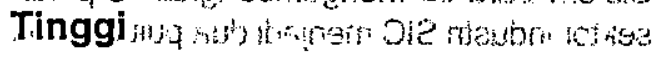
this cirque du Solejl berhasil karena

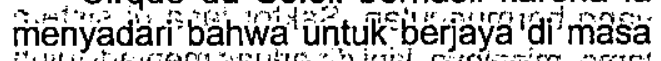

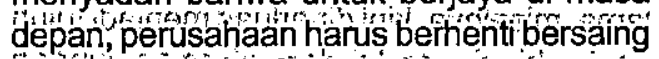
satu sama lain Satu-satunya cará memenangi kompetistadála berhenti berusaha

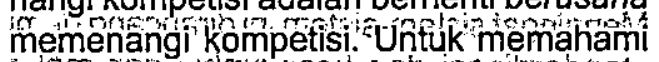
apar yang telah dicáai citrque dúsoleil;

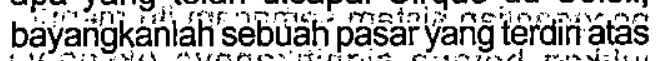

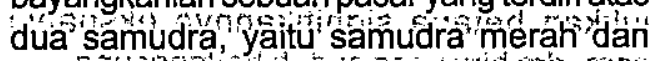

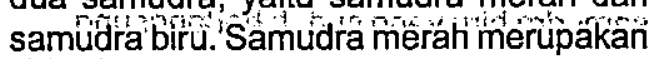
sèmuá industrilyangada'saat in. Ini adalah rùànğg pasar yang sưdat dikenal:Samùdra birư: Imeñandákân! in'dustritindústri yang

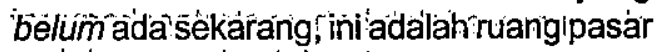

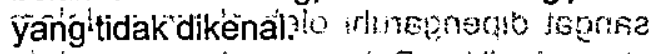
- Dalam samudra merahn batasan-

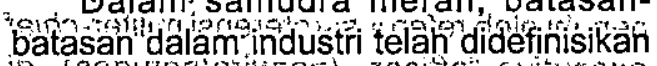
dan diterima, dan âturan-aturan pétsaingan

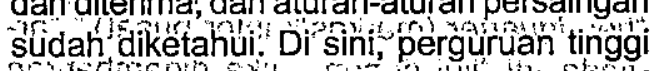
berusaha mengallankan lawan meréka demi

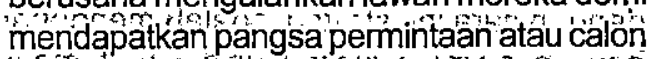

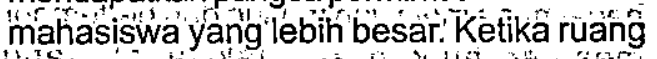

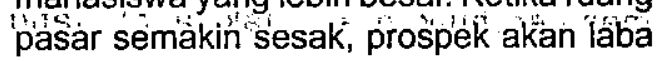

dan, pertumbuhan pun berkurang. Jika hal ini:terjadi, makarperguruan tinggi, akan, berhenti untuk:mengembangkan diri, kecuali, jika:Yayasan perguruan tinggistersebut mempunyai idana yang memadai, Produk dari perguruan tinggimenjadikomoditas dan kompetisi jor-joran mengubah samudra merah menjadisamudra penuh darah:,$\cdots$, ,

- ir iSebàliknỳa, 'samúdrä birú ditandai oleh

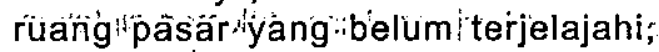
pénciptaan permintaan, dan peluang peertứmì-bühän ýàng̀ sàngat menguntungkan: Mëskipuñ sêjumlah̆ samüudra biru diciptakan

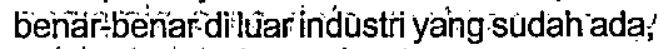
kebányakañ dibuaat: dan dalam "isamudra merah dengan cara mềmperluás'bátasanbatasan industri yang sudah ada, sebagai-

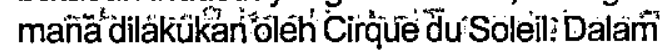
samudra biru, kompetisi itu tidak relevan karena aturan-aturan permainan baru akan

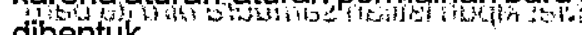

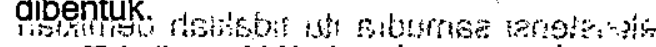
nsw Tak dipungkiri bahwa berenang dengan sukses di disamudra merah dengan cara mengalahkan pesaing akan selalu menjadi hal penting. Samudra merah akan selalu

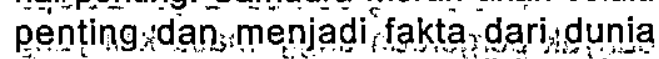
pendidikan Tetapi, dengan kondisi pasokan yangmelebihi permintaan di sebagian besar industri; berkompetisi merain pangsa dari pasaryang berkontraksi, meski:perlu tidak akan memadai untuk mendukung kinerja prima Perguruan tinggi perlü melampaui kompetisi zuntuk meraih laba dan kesempatan pertumbutuan baru, perguruan tinggisuga perlu menciptakan samudra biru. ":tersayangnyai,'samudra! birus sebagian besar belumiterpetakani: Fokus dominan dari kerjarstrategis Yselama: 25stahun terakhir yang'dilakukan Kim dan Mauborgne (2005) selaluipadá strategi sämudra:merah yang berbàsiskan "kompetisis. Hasilnyar adalah pemahamani iyang:cukup baik mengenai bagaimana bersaing, dengan tangkas di perairan merah, rmulai dari menganalisis 
struktur ekonomi yang mendasari sebuah industri, memilih posisi biaya rendah atau diferensiasi atau fokus yang strategis, hingga melakukan perbandingan dengan pesaing (benchmarking) dalam kompetisi. Memang ada sejumlah pembahasan mengenai samudra biru. Namun, hanya ada sedikit panduan praktis mengenai bagaimana menciptakan samudra biru itu. Tanpa kerangka kerja analitis untuk men-ciptakan samudra biru dan prinsip-prinsip untuk mengelola risiko secara efektif, menciptakan samudra biru hanya menjadi impian semata yang dipandang oleh para pimpinan perguruan tinggi sebagai terlalu berisiko untuk dijadikan strategi.

\section{Penciptaan Tiada Henti Samudra Biru (Blue Oceans)}

Meskipun istilah samudra biru itu baru, eksistensi samudra itu tidakiah demikian adanya. Samudra biru juga merupakan bagian dari dunia pendidikan, di masa kini dan masa silam. Mari menengok seratus tahun ke belakang dan bertanya: Berapa banyak perguruan tinggi masa kini yang seratus tahun silam itu belum dikenal? Banyak industri dasar seperti.jndustri mobil, rèkaman musik, penerbangan, petrokimia, layanan kesehatan, dan konsultan manajemen yang belum pernah terdengar atau baru muncul pada saat itu. Kini,. mari kita cukup menengok ke masa tiga puluh tahun yang silam. Kembali, bermunculan sekian ragam industri jutaan dolarreksadana, telepon seluler, pembangkit listrik tenaga gas, bioteknologi, toko rabat, pengiriman paket kilat, minivan, papan luncur, kedai kopi, dan video sewaan, untuk menyebut segelintir contoh. Hanya tiga dasawarsa lalu, tak satu pun dari industriindustri ini yang eksis secara berarti.

Kini, mari kita maju dua puluh tahunatau mungkin lima puluh tahun-ke depan dan tanyai diri kita berapa banyak industri tak dikenal sekarang ini yang akan eksis di masa depan itu. Jika sejarah adalah landasan untuk meramalkan masa depan, jawaban pertanyaan ini adalah: banyak sekali.

Realitasnya, industri tak pernah diam di tempat. Industri selalu berevolusi. Kegiatan operasional berkembang, pasar meluas, dan pemain datang dan pergi. Sejarah mengajarkan bahwa kita memiliki kapasitas besar-yang selama ini kita remehkan untuk menciptakan industri-industri baru dan menciptakan ulang industri-industri yang sudah ada. Sebenamya, sistem Standard Industrial Classification (SIC) berusia 50 tahun yang dikeluarkan oleh US Census telah digantikan pada 1997 oleh sistem North America Industry Classification Standard. Sistem baru ini mengembangkan sepuluh sektor industri SIC menjadi dua puluh untuk menggambarkan realitas teritori-teritori baru yang bermunculan. Sektor jasa di sistem lama, misalnya, kini diperluas menjadi tujuh sektor bisnis, mulai dari informasi hingga layanan kesehatan hingga bantuan sosial. Mengingat sistem-sistem ini dirancang demi standardisasi dan kesinambungan,maka penggantian sistem semacam itu menunjukkan betapa signifikannya ekspansi samudra biru yang sudah berlangsung.

Pemikiran strategis selama ini lebih difokuskan pada strategi samudra merah yang berbasiskan-kompetisi. Sebagian alasannya adalah bahwa strategi korporat sangat dipengaruhi oleh akarnya dalam strategi militer. Bahasa strategi sangat dipenuhi oleh referensi-referensi militer-chief executive "officers (perwira/petugas)" di. "headquarter (markas/kantor pusat)," "armada" di "lini depan". Jika digambarkan dengan cara ini, strategi adalah mengenai bagaimana melawan musuh dan bertempur memperebutkan sepetak tanah yang 
terbatas dan berjumlah tetap.' Tidak seperti perang, sejarah industri menunjukkan bahwa pasar tidak pernah konstan atau tetap. Sebaliknya, sepanjang waktu terlihat bermunculan samudra biru secara terusmenerus. Karena itu, berfokus pada samudra merah sama dengan menèrima faktor-faktor penghambat utama dalam perang-daerah yang terbatas dan perlunya mengalahkan musuh untuk bisa berhasil dan sama dengan menolak kelebihan khas dan dunia bisnis: kemampuan untuk menciptakan ruang pasar baru yang belum ada pesaingnya.

\section{Dampak Penciptaan Samudra Biru}

Dalam sebuah studi tentang inisiatif bisnis di 108 perusahaan, Kim dan Mauborgne (2005) berusaha mengukur secara kuantitatif dampak penciptaan samudrabiruterhadap pertumbuhan pemasukan dan laba perusahaan. Kim dan Mauborgnemenemukan, bahwa 86 persen dari inisiatif itu adalah ekstensi atau perluasan lini, yaitu perbaikan besar dalam samudra merah ruang pasar yang sudah ada. Tetapi, inisiatif itu hanya mewakili 62 persen pemasukan total dan 39 persen laba total, sedangkan sisa 14 persennya adalah inisiatif-inisiatif yang bertujuan menciptakan samudra biru. Inisiatif ini menghasilkan 38 persen pemasukan total dan 61 persen laba total. Inisiatif-inisiatif bisnis mencakup investasi total untuk menciptakan samudra merah dan biru (terlepas dari akibat inisiatif-inisiatif itu terhadap pemasukan dan laba, termasuk akibat berupa kegagalan), manfaat dan menciptakan perairan biru tampak jelas. Meskipun kita tidak memiliki data mengenai tingkat keberhasilan inisiatif-inisiatif samudra merah dan biru, perbedaan kinerja di antara inisiatif-inisiatif itu di tingkat global cukup nyata.

\section{Inovasi Nilai: Batu-Pijak Strategi Samudra Biru}

Hal yang secara konsisten membedakan pemenang dan pecundang dalam menciptakan samudra biru adalah pendekatan mereka atas strategi. Perusahaan yang terperangkap dalam samudra merah mengikuti pendekatan konvensional, yakni berlomba memenangi kompetisi dengan membangun posisi kokoh dalam tatanan industri yang ada. Kreator dari samudra biru, secara mengejutkan, tidak menggunakan kompetisi sebagai patokan mereka. Sebaliknya, mereka mengikuti logika strategis berbedayang kami sebut inovasinilai. Inovasi nilai merupakan batu-pijak daristrategi samudra biru. Kami menyebutnya inovasi nilai karena alih-alih berfokus pada memenangi kompetisi, Anda berfokus menjadikan kompetisi itu tidak relevan dengan menciptakan lompatan nilai bagi pembeli dan perusahaan Anda. Dengan demikian, Anda sekaligus membuka ruang pasar yang baru dan tanpa pesaing.

Inovasi nilai memberikan penekanan setara pada nilai dan inovasi. Nilai tanpa inovasi cenderung berfokus pada penciptaan nilai daiam skala besar, sesuatu yang meningkatkan nilai tapi tidak memadai untuk membuat Anda unggul secara menonjol di pasar. Inovasi tanpa nilai cenderung bersifat mengandalkan teknologi, pelopor pasar, atau futuristis, dan sering membidik sesuatu yang belum siap diterima dan dikonsumsi oleh pembeli. Dalam pengertian ini, penting untuk membedakan antara inovasi nilai, inovasi teknologi, dan usaha menjadi pelopor pasar. Studi menunjukkan bahwa yang memisahkan pemenang dari pecundang dalam menciptakan samudra biru bukanlah teknologi super canggih maupun "waktu yang tepat untuk memasuki pasar." Terkadang hal-hal itu diperiukan; tapi seringnya tidak. Inovasi nilai terjadi hanya 
ketika perusahaan memadukan inovasi dengan utilitas (manfaat), harga, dan posisi biaya. Jika mereka gagal memadukan inovasi dan nilai dengan cara ini, para inovator teknologi dan pelopor pasar sering hanya memberikan telor yang akan ditetaskan oleh perusahaan-perusahaan lain.

Inovasi nilai merupakan cara baru untuk memikirkan dan melaksanakan strategi yang mengarah pada penciptaan samudra biru dan ditinggalkannya kompetisi. Inovasi nilai menolak salah satu dari dogma yang paling umum diterima dalam strategi berbasiskan-kompetisi: dilema/pertukaran (tradeoff) nilai-biaya. Secara umum, diyakini bahwa perusahaan hanya dapat menciptakan nilai lebih tinggi bagi pelanggan dengan biaya tinggi atau menciptakan nilai fumayan dengan biaya lebih rendah. Di sini, strategi dilihat sebagai membuat pilihan antara diferensiasi dan biaya rendah. Sebaliknya, perusahaan yang berusaha menciptakan samudra biru' mengejar diferensiași dan biaya rendah secara bersamaan.

Mari kita tengok kembali contoh Cirque du Soleil. Mengejar diferensiasi dan biaya rendah secara bersamaan bertumpu pada inti dari pengalaman hiburan yang diciptakan Cirque. Pada saat debut Cirque, sirkus-sirkus lain berfokus pada saling membandingkan pesaing dan memaksimalkan pangsa permintaan mereka yang sudah menciut dengan cara mengerahkan habis-habisan berbagai pertunjukan sirkus tradisional. Pengerahan habis-habisan ini meliputi usaha perekrutan lebih banyak badut dan pawang singa terkenal, sebuah strategi yang melambungkan struktur biaya sirkus tanpa secara substansial mengubah pengalaman menyaksikan sirkus. Hasilnya adalah biaya yang meroket tanpa diiringi peningkatan pemasukan, dan menurunnya permintaan akan sirkus secara keseluruhan.
Kemunculan Cirque du Soleil membuat upaya-upaya itu tak lagi relevan. Keberadaan Cirque yang bukan sebagai sirkus biasa maupun produksi teater klasik membuatnya tidak ambil peduli dengan apa yang dilakukan para pesaing dalam kompetisi. Daripada mengikuti logika konvensional untuk memenangi kompetisi dengan menawarkan solusi lebih baik terhadap satu permasalahan-yaitu solusi berupa menciptakan sirkus yang menjanjikan kesenangan dan kegairahan yang lebih besar-Cirque berusaha menawari orang dengan kesenangan dan kegairahan sirkus dan kerumitan intelektual serta kekayaan artistik dari teater pada saat yang bersamaan; jadi, Cirque meredefinisikan masalah itu sendiri. Dengan mendobrak batasan-batasan pasar dari teater dan sirkus, Cirque du Soleil memperoleh pengertian baru bukan hanya dari konsumen sir-kus, melainkan juga dari nonkonsumen sirkus: konsumen atau penikmat teater dewasa.

Hal ini menghasilkan sebuah konsep sirkus baru yang mematahkan dilema/ pertukaran biaya-nilai dan menciptakan samudra biru berupa ruang pasar baru. Simak perbedaan-perbedaan ini. Sementara sirkussirkus lain berfokus pada menawarkan pertunjukan-pertunjukan binatang, merekrut artis bintang, menampilkan beragam arena pertunjukan dalam tiga pentas lingkaran, serta berusaha mendongkrak penjualan karcis diskon untuk jalur di antara deretan tempat duduk (aisle), Cirque du Soleil tidak ambil pusing dengan segala faktor itu. Faktor-faktor mi telah lama diterima begitu saja dalam industri sirkus tradisional; yang tidak pernah mempertanyakan relevansi dari faktor-faktor tersebut. Akan tetapi, protes publik terhadap penggunaan binatang dalam sirkus mulai meningkat. Selain itu, pertunjukan binatang adalah salah satu dari elemen termahal, 
karena tidak hanya mencakup harga binatang itu sendiri, tapi juga biaya pelatihan, layanan kesehatan, kandang, asuransi, dan transportasi bagi binatang tersebut.

Sementara industri sirkus berfokus pada menampilkan bintang-bintang, publik awam merasa bintang-bintang sirkus tidaklah setara dengan bintang film. Padahal, bintang sirkus juga merupakan komponen berbiaya tinggi yang tidak punya efek besar kepada penonton. Cirque juga membuang tiga pentas lingkaran yang umum dalam sirkus tradisional. Pengaturan tiga pentas lingkaran seperti ini sebenarnya menimbulkan kegelisahan di antara penonton karena mereka harus secara cepat mengalihkan pandangan mereka dari satu lingkaran ke lingkaran lain. Selain itu, pengaturan tiga pentas juga meningkatkan jumlah pementas yang dibutuhkan dan ini tentu berujung pada membengkaknya biaya. Meskipun penjualan karcis diskon untuk jalur di antara tempat duduk penonton tampak sebagai cara yang bagus untuk meningkatkan pemasukan, namun pada praktiknya harga yang tinggi mengurungkan niat konsumen untuk membeli dan membuat mereka merasa ditipu.

Daya tariklanggeng dari sirkus tradisional hanya terdiri atas tiga faktor: tenda, badut, dan aksi akrobat klasik seperti pemain roda dan aksi-aksi.maut berdurasi pendek. Jadi, Cirque du Soleil miëmpertahankan badut, tapi mengubah humornya dari slapstik'yang: mengandalkan fisik menjadi lawakan yang lebih intelektual dan memikat. Cirque: membuat tenda lebih glamor, sebuah elemen yang ironisnya mulai diabaikan oleh banyak sirkus demi bisa membayar sewa tanah untuk pertunjukan. Memahami bahwa ciri unik ini secara simbolis mampu menangkap keajaiban sirkus, Cirque du Soleil merancang simbol klasik sirkus dengan tampilan luar yang megah dan tingkat kenyamanan prima. la membuat tenda-tendanya bernuansa sirkus-sirkus epik besar masa lampau. Bangku-bangku keras dan serbuk gergaji juga menghilang. Akrobat dan aksi-aksi mendebarkan lainnya dipertahankan, tapi perannya dibatasi dan dibuat lebih elegan dengan tambahan gaya, artistik dan daya pikat intelektual dalam aksi-aksi itu.

Dengan melirik batasan pasar teater, Cirque du Soleil juga menawarkan elemenelemen nonsirkus, seperti struktur cerita dan, bersama itu, kekayaan intelektual, musik dan tarian artistik; serta beragam pentas karya. Faktor-faktor ini, yang sepenuhnya baru bagi industri sirkus, diambil dari industri-hiburan-langsung alternatif bernama teater.

Tidak seperti pertunjukan sirkus tradisional yang rangkaian aksi-aksinya tidak berkaitan, setiap kreasi Cirque 'du Soleil memiliki tema dan struktur ceritayańg. menyérupai pertunjukan teater: Meskipun temanya kabur (dan mcmang dibuat demikian), tema itu membawa harmoni dan elemen intelektual bagi pertunjukan-tanpa membatasi potensi dari aksi-aksi yang ada. Le Cirque juga mengambil ide dari pertunjukan Broadway. Misalnya, Le Cirque menampilkan beragam produksi dibandingkan pertunjukan tradisional "satu untuk semua". Sama juga dengan pertunjukan Broadway, setiap pertunjukan Cirque du Söreil menampilkan lagu pengiring (original scorej dan beragam musik; yang mengarahkan penataan visual, tatälampū, dän timing. dari aksi-aksi. Pertunjukan-pertunjukannya menampilkan tarian abstrak dan spiritual, sebuah ide yang diambil dari teater dan balet. Dengan memperkenalkan faktor-faktor baru ini, Cirque du Soleil telah menciptakan pertunjukan yang lebih berkelas dengan sofistikasi tinggi. Selain itu, dengan menyuntikkan konsep beragam produksi 
Topik: Globalisasi dan Liberalisasi dalam Bidang Pendidikan

dan dengan memberikan alasan bagi orang untuk lebih sering mengunjungi sirkus, Cirque du Soleil secara dramatis telah meningkatkan permintaan.

Secara singkat, Cirque du Soleil menawarkan elemen terbaik dari sirkus dan teater dan mengurangi atau menghilangkan elemen-elemen remehnya. Dengan menawarkan manfaat yang tak ada sebelumnya, Cirque du Soleil telah menciptakan sebuah samudra biru dan menciptakan bentuk baru dari hiburan langsung, yaitu bentuk yang berbeda dari sirkus tradisional dan teater. Pada saat yang sama, dengan menghilangkan banyak elemen termahal dari sirkus, Cirque secara dramatis telah mengurangi struktur biayanya dan mencapai diferensiasi sekaligus biaya rendah. Le Cirque secara strategis menghargai tiketnya sesuai dengan harga tiket teater. Dengan cara ini, ia menaikkan harga tiket pasaran industri sirkus beberapa kali lipat, tapi tetap mempertahankan harga yang dapat menarik konsumen dewasa, yang sudah terbiasa dengan harga tiket teater.

Penciptaan samudra biru adalah soal menekan biaya sembari meningkatkan nilai bagi pembeli. Beginilah bagaimana lompatan nilai bagi perusahaan dan pembeli dicapai, karena nilai pembeli berasal dari utilitas (manfaat) dan harga yang ditawarkan per-usahaan kepada pembeli, dan karena nilai bagi perusahaan itu dihasilkan dari harga dan struktur biaya maka inovasi nilai - tercapai hanya ketika keseluruhan sistem kegiatan utilitas, harga, dan biaya perusahaan terpadu dengan tepat. Pendekatan keseluruhan sistem inilah yang menjadikan penciptaan samudra biru sebagai sebuah strategi berkesinambungan (sustainable). Strategi samudra biru mengintegrasikan kegiatan-kegiatan fungsional dan operasional perusahaan.
Sebaliknya, inovasi seperti inovasi produksi dapat dilakukan pada level subsistem tanpa memengaruhi keseluruhan strategi perusahaan. Sebuah inovasi dalam proses produksi, misalnya, menurunkan struktur biaya perusahaan untuk memperkuat strategi-kepemimpinan-biaya yang telah ada tanpa mengubah proporsi utilitas dalam penawarannya. Meskipun inovasi semacam ini dapat membantu mempertahankan dan bahkan meningkatkan posisi perusahaan dalam ruang pasar yang ada, pendekatan subsistem yang demikian jarang menciptakan samudra biru berupa ruang pasar baru.

.Dalam pengertian ini, inovasi nilai adalah lebih dari sekadar inovasi. Inovasi nilai adalah soal strategi yang merangkul seluruh sistem kegiatan perusahaan. Inovasi nilai menuntut perusahaan untuk mengarahkan seluruh sistem pada tujuan mencapai lompatan dalam nilai bagi pembeli dan bagi perusahaan itu sendiri.

Strategi samudra merah yang berbasiskan kompetisi mengasumsikan bahwa kondisi-kondisi struktural itu terberi dan bahwa perusahaan dipaksa untuk berkompetisi dalam kondisi-kondisi itu: sebuah asumsi yang didasarkan pada apa yang disebut akademisi sebagai pandangan strukturalis, atau determinisme lingkungan. Sebaliknya, inovasi nilai didasarkan pada pandangan bahwa batasan-batasan pasar dāñ struktur industri tidaklah terberi dan bisa direkonstruksi melalui tindakan dan keyakinan pelaku industri, kami menyebut ini sebagai pan-dangan rekonstruksionis. Dalam samudra merah, diferensiasi menelan biaya besar karena perusahaan berkompetisi berdasarkan aturan praktik sukses yang sama. Dalam samudra biru, pilihan strategis bagi perusahaan adalah mengejar baik diferensiasi maupun biaya rendah. $\mathrm{Di}$ sisi lain, dalam pandangan rekonstruksionis, 
tujuan strategi adalah menciptakan aturanaturan praktik sukses baru dengan mendobrak dilema/pertukaran nilai-biaya yang ada dan, dengan demikian, menciptakan samudra biru.

Cirque du Solei mendobrak aturan praktik sukses dari industri sirkus, dan mencapai diferensiasi sekaligus biaya ren-dah dengan merekonstruksi elemenelemen lain dalam batasan-batasan industri yang ada. Apakah Cirque du Soleil itu benarbenar sirkus, dengan semua elemen yang dibuang, dikurangi, ditambah, dan diciptakan? Ataukah sebuah teater?-Dan, jika ia sebuah teater, tergolong pada genre apa-pertunjukan Broadway, opera, balet? Tidaklah jelas. Cirque du Soleil merekonstruksi elemen-elemen lain melampaui alternatif-alternatif ini dan, pada akhirnya, ia adalah gabungan dari kepingan-kepingan kecil semua alternatif tadi sekaligus juga bukan secara tegas bisa tergolong ke dalam salah satu alternatif. Cirque du Soleil menciptakan samudra biru berupa ruang pasar baru yang belum ada pesaingnya dan belum diberi nama.

\section{Kerangka Kerja dan Alat Analisis}

Kim dan Mauborgne (2005) telah menghabiskan satu dasawarsa terakhir untuk mengembangkan seperangkat kerangka kerja dan alat analisis agar perumusan dan penerapan strategi samudra biru sama sistematis dan praktisnya dengan berkompetisi di perairan merah dalam ruang pasar yang sudah dikenal. Perangkat analisis ini mengisi kekosongan utama di bidang strategi, yang selama ini telah mengembangkan sejumlah besar alat dan kerangka kerja mengesankan untuk bersaing dalam samudra merah seperti lima kekuatan (five forces) untuk menganalisis kondisi-kondisi industri yang sudah ada dan tiga strategi generic namun tak banyak berkiprah dalam pengembangan alat-alat praktis untuk berjaya di samudra biru. Para. eksekutif malah diseru untuk bérāni dan berjiwa wirausaha, untuk belajar dari kegagalan, dan untuk mencari langkahlangkah revolusioner. Meskipun provokatif secara wacana, seruan itu bukanlah pengganti bagi perangkat analisis yang diperlukan untuk mengarungi samudra biru dengan selamat. Tanpa perangkat analisis, para eksekutif tak bisa. diharapkan memenuhi seruan untuk keluar dari kompetisi yang ada. Strategi samudra biru yang efektif haruslah berkenaan dengan minimalisasi risiko, bukan mengambil risiko.

Untuk mengatasi ketidak seimbangan ini, Kim dan Mauborgne mempelajari perusahaan-perusahaan diselúruh dunia dan mengembangkan beberapa metodologi praktis dalam petualangan samudra biru. Kim dan Mauborgne kemudian menerapkan dan menguji alat-alat dan kerangka kerja ini pada tataran praktis melalui proses kerja dengan perusahaan-perusahaan yang berusaha menerapkan samudra biru, dan memperkaya serta mempertajam samudra itu dalam proses tersebut. Alat-alat dan kerangka kerja yang Kim dan Mauborgne ini akan digunakan untuk kasus perguruan tinggi di Indonesia.

Kompetisi yang ketat telah memicu terjadinya konsolidasi industri yang tiada henti. Lebih dari 1300 perguruan tinggi swasta dan lebih dari 75 perguruan tinggi negeri. Beberapa dari perguruan tinggi swasta mengucurkan jutaan rupiah untuk pemasaran above-the-line. Tidaklah mengherankan jika semakin banyak perguruan tinggi kecil yang tersapu keluar. Lebih lagi dengan datangnya perguruan tinggi asing. Pendek kata, perguruan tinggi di Indonesia ditambah dengan masuknya perguruan tinggi asing akan menghadapi kompetisi yang ketat, tekanan biaya yang 
mèningkat; "dayà täwar ýàng menguat darí pihak calon mánasiswà; dañ permintaan yang staǵnan kendati pilihan șemakin banyâk. 'Jika menigikuti pemikiran stràtegis'

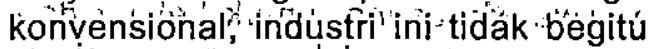
menárik. Bàgi pâra ah'li'stratégi, pertanyàan pentingnya adalah : Bagäimana perguruan tinggi imelepaskản diri dari śámưudra mêrah

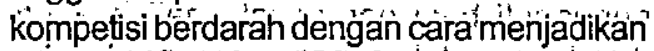

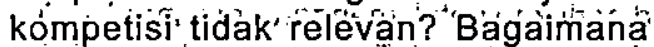
pergưuian tinggi mémbúka dan mênangkà samúdra biru dẩi ruanig pàsär ỷảng belum

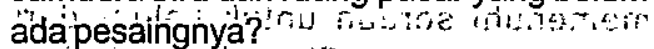

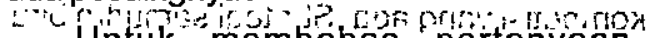
- Untuk membahas pertanyaanpertanyaan ini, akan dibanas kanvas strategi, sebuah kerangka kejua analitis yang

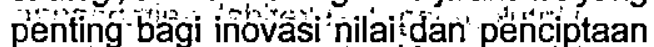

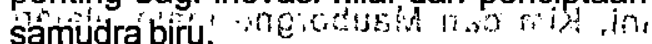

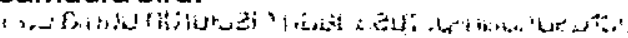

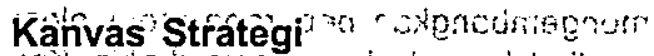

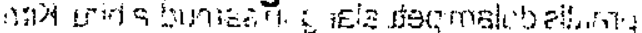
Kanvas strategi adalah kerangka akssi sekaligus diagnosis untuk membangun strategi dua fungsi (Kim dan Mauborgne; 2005). Pertama; Kim dan Mauborgne merangkum situasi i terkinizdalam-ruang pasar yang sudah dikenal Hal $_{\text {in }}$ in memungkinkan:perguruan tinggi untuk memahami, dimana-kompetisi saat ini sedang tercurah, memahami, faktor-faktor

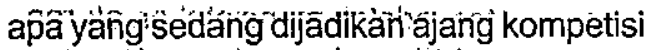

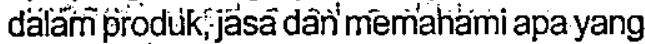

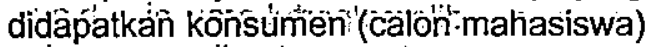

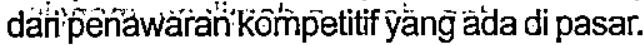
Gambar 1 merangkum sëmùuälinformasi ini. dalam bentuk grafik:s Sumbu horizontal mewakili rentang:faktor;faktoryang dijadikan, ajangikompetisidan:investasijoleh industri: - ner Dàlam kasúsústiǹdustrì pendidikan di In-

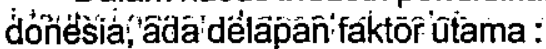

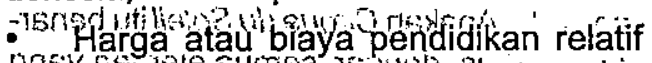

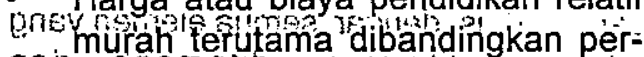
ros guruan ting ns dibanding inan rata-ratán perguruan tinggi ensonswe ditin sioswasta di noonesia.

- jolstogan yang dipakai dalam meng-

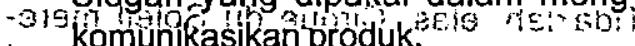

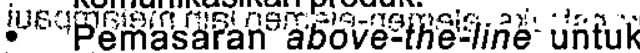

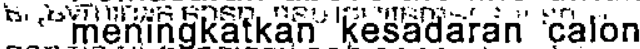

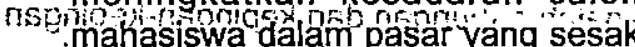

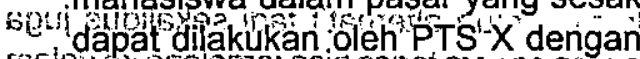

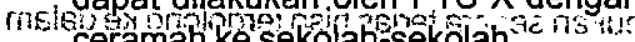
!oo grtsioputas akadenk ro dipaksakan denganpendanaan yang besar, tetapi tetap diupayakan secara proporsional.

- Citra Perguruan Tinggi Yogyakarta

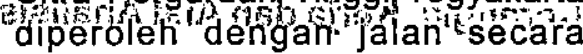
rislepropoirsionat melalui hasil:karya ilmiah

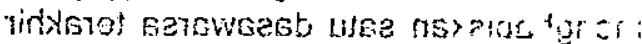

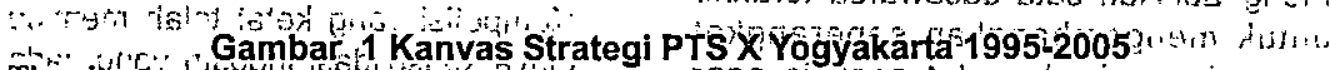

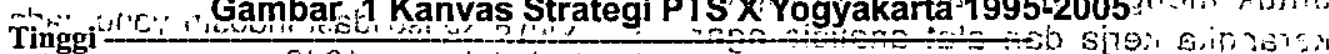

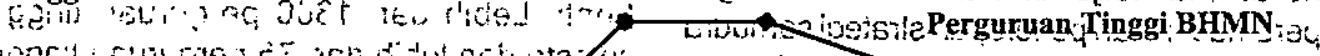

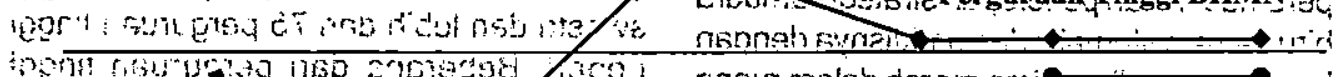

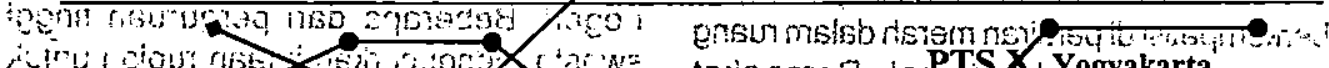

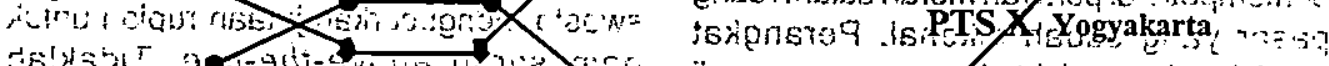

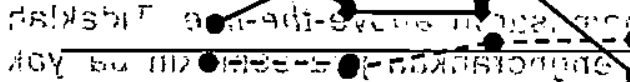

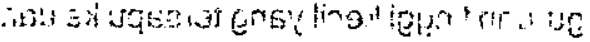

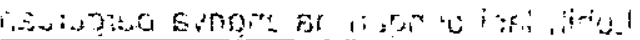

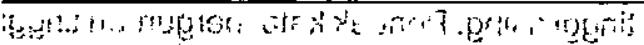

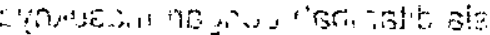
Rendah-

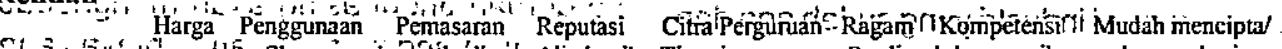

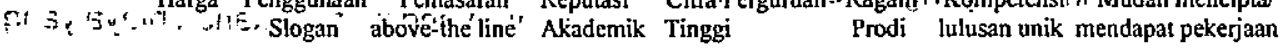


baik melalui jurnal ilmiah maupun buku referensi serta hasil karya professional, misalnya film kartun yang sudah mampu melakukan ekspor.

- Ragam program studi di Perguruan Tinggi Yogyakarta tidak sebanyak di perguruan tinggi BHMN, tetapi dengan konsentrasi yang bersifat unik yang belum ada dapat menciptakan samudra biru.

- Kompetensi lulusan unik.

- Kemudahan lulusan untuk menciptakan pekerjaan atau mendapatkan pekerjaan. Faktor-faktor ini dianggap elemen penting dalam promosi perguruan tinggi dalam persaingan yang sangat ketat. Demikianlah struktur dasar dari perguruan tinggi di Indonesia berdasarkan persepsi pasar. Pada sumbu vertikal dari kanvas strategi, yang merangkum tingkat penawaran yang didapatkan calon mahasiswa di semua faktor utama kompetisi tadi. Skor tinggi menandakan sebuah perguruan tịnggi memberikan penawaran lebih kepada konsumen, sekaligus menandakan perguruan tinggi itu mengeluarkan investasi lebih banyak pada faktor tersebut. Dalam kasus harga, skor lebih tinggi semakin mahal kuliah di perguruan tinggi tersebut. Kita sekarang bisa memetakan penawaran mutakhir yang dilakukan perguruan tinggi mengenai faktor-faktor ini untuk memahami profil strategis perguruan tinggi atau kurva nilai. Kurva nilai, komponen dasar dari kanvas strategi, adalah penggambaran grafis mengenai kinerja relative perguruan tinggi berkenaan dengan faktor-faktor kompetisi dalam industri.

Gambar 1 menunjukkan, meskipun lebih dari 1300 perguruan tinggi yang terjun ke dalam industri pendidikan, namun dari sudut pandang pembeli (calon mahasiswa), ada titik temu (konvergensi) yang besar dalam kurva nilai perguruan tinggi itu.
Meskipun terdapat jumlah kompetitor yang besar, ketika perguruan tinggi unggul (BHMN) dipetakan dalam kanvas strategi, kita mendapati bahwa dari sudut pandang pasar, semuanya secara esensial memiliki profil strategis yang sama. Mereka menawarkan harga tinggi dan tingkat penawaran tinggi berkenaan dengan semua faktor kompetisi. Profil strațegis mereka mengikuti strategi diferensiasi klasik. Namun, dari sudut pandang, pasar, mereka semua berbeda pada hal-hal yang sama. $\mathrm{Di}$ sisi lain, perguruan tingigi swasta juga memiliki profil strategi esensial yang sama. Harganya rata-rata relatif rendah, demikian pula penawaran yang mereka berikan berkenaan dengan semua faktor kompetisi. Mereka adalah pemain pasar klasik berbiaya-rendah. Selain itu, kurva nilai dari perguruan tinggi unggul dan perguruan tinggi swasta memiliki bentuk dasar yang sama. Strategi dari dua kelompok strategi ini sangat mirip, tapi dengan tingkat pembeṛian penawaran yang berbeda.

Supaya bisa meluncurkan perguruan tinggi ke lintasan pertumbuhan yang kuat dan menguntungkan di tengah kondisikondisi industri ini, tidaklah banyak bermanfaat bila membuat perbandingan dengan pesaing dan berusaha mengalahkan mereka dengan memberi penawaran lebih banyak atau lebih sedikit. Strategi semacam itu bisa saja meningkatkan minat calon mahasiswa yang masuk, tapi tidak akan bisa mendorong perguruan tinggi untuk membuka ruang päsar yang belum ada pesaingnya. Melakukan penelitian calon mahasiswa secara mendalam juga tak banyak berguna untuk meciptakan samudra biru. Penelitian Kim dan Mauborgne menemukan bahwa para konsumen jarang bisa membayangkan bagaimana cara menciptakan ruang pasar yang belum ada pesaingnya. Wawasan mereka juga 
cenderung mengarah pada ungkapan lama "tawari aku lebih banyak dengan harga lebih murah." Dan, hal yang konsumen ingin dapatkan secara lebih "banyak" adalah fiturfitur produk dan jasa ditawarkan industri saat ini.

Untuk mengubah secara fundamental kanvas strategi suatu industri, perguruan tinggi harus mulai dengan mengarahakan kembali fokus strategi dari pesaing ke alternative, dan dari konsumen ke nonkonsumen industri tersebut. Untuk mengejar nilai tinggi sekaligus biaya rendah, perguruan tinggi harus melawan logika lama : membanding-bandingkan pesaing dalam bidang yang ada dan memilih antara diferensiasi ataukah kepemimpinan biaya. Ketika perguruan tinggi menggeser fokus strategi dari kompetisi saat ini ke arah alternatif dan nonkonsumen, perguruan tinggi akan medapatkan pemahaman bagaimana meredefinisikan masalah yang dihadapi industri dan, karenanya, merekonstruksi èlemen-elemen nilai pembeli yang ada di sepanjang batas-batas industri. Sebaliknya, logika strategi konvensional menuntut perguruan tinggi menawarkan solusi lebih baik dibanding yang ditawarkan pesaing perguruan tinggi bagi masalah-masalah yang sudah didefinisikan oleh industri tempat perguruan tinggi berada.

Untuk merekonstruksi elemen-elemen nilai pembeli dalam membuat kurva nilai baru, kami telah mengembangkan kerangka kerja empat langkah. Supaya dapat mendobrak dilemma/pertukaran antara diferensiasi dan biaya rendah serta agar dapat menciptakan kurva nilai baru, ada empat pertanyaan kunci untuk menantang logika strategi dan model bisnis sebuah industri.

- Faktor apa saja harus dihapuskan dari faktor-faktor yang telah diterima begitu saja oleh industri?

- Faktor apa saja yang harus dikurangi hingga di bawah standar industri?
- Faktor apa saja yang harus ditingkatkan hingga di atas standar industri?

- Faktor apa saja yang belum pernah ditawarkan industri sehingga harus diciptakan?

Pertanyaan pertama memaksa perguruan tinggi mempertimbangkan penghilangan faktor-faktor yang sudah lama menjadi ajang persaingan bagi antar perguruan tinggi dalam industri pendidikan. Sering kali, faktor-faktor ini diterima begitu saja, meskipun faktor-faktor tersebut tidak lagi memiliki nilai atau bahkan mungkin mengurangi nilai. Terkadang, ada perubahan fundamental dalam apa yang dihargai sebagai nilai oleh pembeli, tapi perusahaan yang berfokus pada pembandingan diri (benchmark) satu sama lain tidak menanggapi, atau bahkan tidak melihat, perubahan itu.

Pertanyaan kedua memaksa perguruan tinggi menentukan apakah produk atau jasa perguruan tinggi selama ini dirancang terlalu berlebihan untuk mengikuti irama kompetisi dan mengalahkannya. Disini; perguruan tinggi terlalu berlebihan dalam melayani mahasiswanya dan meningkatkan struktur biaya mereka tanpa menghasilkan apa-apa.

Pertanyaan ketiga mendorong perguruan tinggi untuk menguak dan menghilangkan kompromi-kompromi yang dipaksakan industri kepada konsumen. Pertanyaan keempat membantu perguruan tinggi menemukan sumber-sumber nilai yang sepenuhnya baru bagi calon mahasiswa dan menciptakan permintaan baru serta mengubah pemberian harga strategis industri.

Dengan membahas dua pertanyaan pertama (soal menghilangkan dan mengurangi), perguruan tinggi bisa mendapatkan pengetahuan tentang bagaimana menurunkan struktur biaya perguruan tinggi terhadap 
pesaing. Penelitian Kim dan Mauborgne menemukan bahwa manajer jarang sekali secara sistematis berusaha menghilangkan dan mengurangi investasi dalam faktor-faktor yang menjadi ajang kompetisi dalam industri. Hasilnya adalah peningkatan struktur biaya dan model-model bisnis kompleks. Dua faktor yang akhir, sebaliknya, memberi perguruan tinggi pengetahuan tentang. bagaimana meningkatkan nilai pembelian dan menciptakan permintaan baru. Secara bersama-sama, keempat pertanyaan ini memungkinkan perguruan tinggi secara sistematis mengeksplorasi cara perguruan tinggi merekonstruksi elemen-elemen nilai pembeli di sepanjang industri-industri alternative demi menawari pembeli pengalaman yang sama sekali baru, sambil secara bersamaan tetap mempertahankan struktur biaya perguruan tinggi pada level rendah. $\mathrm{Hal}$ yang juga penting adalah tindakan-tindakan membuang dan menciptakan, yang mendorong perusahaan untuk melangkah melampaui praktik maksimalisasi nilai dari faktor-faktor yang ada dalam kompetisi. Tindakan membuang dan menciptakan mendorong perusahaan untuk mengubah faktor-faktor itu sendiri, dan karenanya sekaligus membuat aturan-aturan, yang ada dalam kompetisi menjadi tidak relevan.

Ketika perguruan tinggi menerapkan kerangka kerja empat langkah ini pada kanvas strategi industri perguruan tinggi, perguruan tinggi akan mendapatkan wawasan baru dan mencerahkan mengenai kebenaran-kebenaran lama.

Alat alat ketiga penting dalam menciptakan samudra biru. Alat ini adalah alat analisa pelengkap bagi kerangka kerja empat langkah. Alat ini disebut Skema Hapuskan-Kurangi-Tingkatkan-Ciptakan (lihat skema 1). Skema ini mendorong perguruan tinggi untuk tidak hanya menanyakan empat pertanyaan dalam kerangka kerja empat langkah, tapi juga bertindak berdasarkan keempat pertanyaan itu untuk menciptakan suatu kurva nilai baru.

Dengan mendorong perguruan tinggi mengisi skema dengan tindakan-tindakan menghapuskan, mengurangi, meningkatkan, dan menciptakan, skema ini memberikan empat manfaat utama kepada lembaga:

la mendorong perguruan tinggi untuk mengejar diferensiasi dan biaya murah secara bersama untuk mendobrak pertukaran nilai-nilai.

la segera menghantam perguruan tinggi yang hanya berfokus pada upaya meningkatkan dan menciptakan, sehingga menaikkan struktur biaya mereka, serta menghantam perguruan tinggi yang sering, memodifikasi produk dan jasa secara berlebihankesalahan umum.

\section{Skema 1 Skema Hapuskan-Kurangi-Tingkatkan-Ciptakan : Kasus (Yellow trail)}

\begin{tabular}{|c|c|}
\hline $\begin{array}{l}\quad \text { Menghapuskan } \\
\text { Biaya-biaya yang tidak menambah } \\
\text { nilai } \\
\text { Mata program studi / mata kuliah } \\
\text { yang tidak relevan lagi }\end{array}$ & $\begin{array}{l}\text { Meningkatkan } \\
\text { Biaya pendidikan dan laba unit-unit bisnis } \\
\text { Kompetensi-unik yang bertaraf internacional } \\
\text { Public relations lewat karya ilmiah dan karya } \\
\text { profesional }\end{array}$ \\
\hline $\begin{array}{l}\quad \text { Mengurangi } \\
\text { Kerumitan pendaftaran calon } \\
\text { mahasiswa } \\
\text { Pemasaran above - the - line } \\
\text { secara bertahap }\end{array}$ & \begin{tabular}{l}
\multicolumn{1}{c}{ Menciptakan } \\
Kemudahan mendapat pekerjaan \\
Pengusaha-pengusaha dari kampus \\
Keceriaan dan motivasi mahasiswa
\end{tabular} \\
\hline
\end{tabular}


- Skema ini dengan mudah dipahami oleh pimpinan di level apapun, sehingga menciptakan tingkat keterlibatan yang tinggi dalam penerapannya.

- Karena penuntasan upaya-upaya dalam skema ini merupakan tugas menantang, skema ini mendorong perguruan tinggi untuk bersemangat dalam menganalisis setiap faktor industri yang menjadi ajang kompetisi, sehingga ia menemukan berbagai asumsi implisit yang mereka buat secara tak sadar dalam berkompetisi.

\section{Membaca Kurva Nilai Perguruan Tinggi}

Kanvas strategi memungkinkan perusahan untuk melihat masa depan di masa kini. Untuk bisa melakukan ini, perusahaan hàrus memahami cara membaca kurva nilai.

Pernyataan pertama yang dijawab kurva nilai adalah apakah suatu bisnis layak menjadi pemenang. Ketika kurva nilai suatu perguruan tinggi, atau kurva nilai pesaingnya, memenuhi tiga kriteria yang mendefinisikan strategi samudra biru yang bagus, yaitu fokus, divergensi, dan moto memikat yang berbicara kepada pasar perguruan tinggi itu berarti sedang berada di jalan yang benar. Tiga kriteria ini berfungsi sebagai alat uji litmus bagi daya tahan komersil dari ide-ide samudra biru.

Di sisi lain, ketika kurva nilai suatu perguruan tinggi kurang fokus, struktur biayanya akan cenderung tinggi dan model bisnisnya cenderung kompleks untuk diiplementasikan dan dieksekusi. Jika tidak memiliki divergensi, strategi suatu perguruan tinggi hanya menjadi imitator yang tak bisa menonjol dalam ruang pasar. Jika tidak memiliki moto memikat yang mampu menarik pembeli, strategi perguruan tinggi hanya akan menjadi wacana internal atau menjadi contoh klasik dari inovasi demi kepentingan inovasi semata, yang tidak memiliki potensi komersial dan kemampuan alamiah untuk lepas landas.

Ketika kurva nilai suatu perguruan tinggi bertemu dengan kurva nilai pesaingnya, hal ini menandakan bahwa perusahaan tersebut cenderung terperangkap dalam samudra merah kompetisi berdarah. Strategi eksplisit atau implisit perusahaan cenderung berusaha memenangi kompetisi dengan bertumpu pada biaya atau kualitas. Hal ini menandakan pertumbuhan yang lambat, kecuali jika, karena keberuntungan, perguruan tinggi yang sedang bertumbuh. Namun, pertumbuhuan yang demikian tejadi bukan karena strategi perguruan tinggi, melainkan karena keberuntungan.

Ketika kurva nilai suatu perguruan tinggi pada kanvas strategi menunjukkan tingkat yang tinggi dalam semua faktor, pertanyaannya adalah : Apakah pangsa pasar dan profitabilitas perguruan tinggi mencerminkan investasi-investasi ini? Jika tidak, kanvas strategi menandakan bahwa perguruan tinggi mungkin memberikan pasokan berlebih kepada konsumennya atau mahasiswanya, meberikan penawaran terlalu banyak dari elemen-elemen yang memberikan tambahan nilai kepada mahasiswa. Untuk melakukan inovasi nilai, perguruan tinggi harus memutuskan faktorfaktor mana yang harus dihapuskan dan dikurangi bukan hanya nilai-nilai yang harus ditingkatkan dan diciptakan untuk membangun kurva nilai yang divergen.

Ketika kurva nilai suatu perguruan tinggi terlihat seperti gerak zig-zag tanpa pola atau alasan jelas, dimana penawaran dapat digambarkan sebagai "rendah - tinggi rendah - rendah - tinggi - rendah - tinggi" maka hal itu menandakan bahwa perguruan 
tinggi tidak memiliki strategi yang koheren. Strategicenderung didasarkan pada berbagai sub strategi yang terlepas sendiri-sendiri. Sub-sub strategi ini mungkin masuk akal dan membuat bisnis berjalan dan semua orang bekerja, tapi secara kolektif sub-sub strategi itu tidak banyak bermanfaat dalam membedakan perguruan tinggi dari pesaing utama atau dalam membangun visi suatu strategis yang jelas. Hal. ini sering merupakan cerminan dari suatu organisasi dengan sekat-sekat divisional atau fungsional.

Apakah kontradiksi strategis ?. Kontradiksi strategis merupakan area dimana suatu perguruan tinggi memberikan penawaran tingkat tinggi pada sutu faktor kompetisi, sementara ia mengabaikan areaarea lain yang mendukung faktor tersebut. Satu contoh adalah menanamkan investasi besar dalam membuat situs internet perguruan tinggi yang mudah digunakan, tapi lalai membenahi lambatnya kecepatan operasi dari situs tersebut. Inkonsistensi strategis juga bisa ditemukan antara tingkat penawaran dan harga. Misalnya, suatu perguruan tinggi mendapati bahwa dirinya menawarkan "less for more" : pelayanan yang lebih buruk daripada pesaing utama ditambah harga yang lebih mahal. Tidak heran jika perguruan tinggi itu dengan cepat kehilangan pangsa pasarnya.

Dalam menggambar kanvas strategi bagaimana perguruan tinggi melabeli faktorfaktor kompetisi dalam industri ? Apakah faktor-faktor kompetisi dinyatakan dalam istilah-istilah yang dapat dipahami dan dihargai oleh pembeli (calon mahasiswa), ataukah dinyatakan dalam jargon operasional ? Jenis bahasa yang digunakan dalam kanvas strategi memberikan pengetahuan apakah visi strategis suatu perguruan tinggi dibangun berdasarkan perspektif "luar - ke-dalam" yang didorong oleh sisị permintaan, ataukah berdasarkan perspektif "dalam-ke-luar" yang didorong secara operasional. Menganalisis bahwa kanvas strategi membantu perguruan tinggi memahami sejauhmana mereka mampu menciptakan permintaan dalam industri.

Alat-alat dan kerangka kerja yang diperkenalkan di sini adalah alat analisis penting Persinggungan antara teknik-teknik analisis dan enam prinsip dalam merumuskan dan menerapkan samudra birulah yang memungkinkan perguruan tinggi menjauh dari kompetisi dan membuka ruang yang belum ada pesaingnya.

\section{Penutup}

Hadirnya perguruan tinggi asing akan semakin meningkatkan persaingan perguruan tinggi di Indonesia. Strategi bersaing pada persaingan yang sangat ketat dapat menimbulkan "lautan darah" bagi perguruan tinggi yang bersaing atau bertarung tersebut. Strategi ini- disebut sebagai Bloody or Red Ocean Strategy (strategi samudra merah). ,

Unntuk mempersiapkan diri dàn terhindar dari persaingan yang sangat ketat ini perguruan tinggi dapat menggunakan Blue Ocean Strategy (strategi samudra biru). Blue Ocean Strategy menganggap bahwa bersaing adalah menciptakan ruang pasar yang tidak ada lawannya.'Pasar yang sangat luas bagaikan "lautan biru". Karena pasar sangat luas, perguruan tinggi dapat memilih pasar sesuka hatinya. Blue Ocean Strategy menggunakan konsep dengan membuat persaingan itu tidak ada. Karena persaingan tidak ada, maka perguruari tinggi hanya bersaing dengan dirinya sendiri tanpa perguruan tinggi lain. Perguruan tinggi tersebut pasti akan memenangkan persaingan tanpa lawan. Blue Ocean Strategy menciptakan dan menangkap permintaan baru. Blue 
Topik: Globalisasi dan Liberalisasi dalam Bidang Pendidikan

Ocean Strategy meraih keunggulan dengan tanpa harus menciptakan nilai. Blue Ocean Strategy bersatu dengan sistem secara keseluruhan dari aktivitas perguruan tinggi dalam melaksanakan strategi diferensiasi dan strategi kepemimpinan biaya keseluruhan secara bersama-sama. Blue Ocean Strategy myangkut dua aspek. Pertama, bagaimana menemukan dan mengembangkan blue ocean. Untuk menemukan dan mengembangkan blue ocean, dengan meluncurkan industri baru yang lengkap dan melakukan yang lebih umum dengan memperluas batas idustri yang diciptakan oleh red ocean. Kedua, bagaimana mengekploitasi dan melindungi blue ocean.

Kanvas strategi adalah kerangka aksi sekaligüs diagnosis untuk membangun strategi dua fungsi. Pertama, ia merangkum situasi terkini dalam ruang pasar yang sudah dikenal. Hal ini memungkinkan perguruan tinggi untuk memhami dimana kompetisi saat ini sedang tercurah, memahami faktorfaktor apa yang sedang dijadikan ajang kompetisi dalam produk, jasa dan memahami apa yang didapatkan konsumen (calon mahasiswa) dari penawaran kompetitif yang ada di pasar.

Strategi samudra biru yang efektif memiliki tiga kualitas yang saling melengapi, yaitu fokus, gerak menjauh (divergensi), dan moto utama. Tanpa kualitas ini, strategi perguruan tinggi akan kabur, tidak khas, sulit dikomunikasikan, dan memiliki struktur biaya tinggi.

Alat-alat dan kerangka kerja yang berupa kanvas strategi, kerangka kerja empat langkah dan skema hapuskankurangi-tingkatkan-ciptakan merupakan alat analisis penting Persinggungan antara teknik-teknik analisis dan enam prinsip dalam merumuskan dan menerapkan samudra birulah yang memungkinkan perguruan tinggi menjauh dari kompetisi dan membuka ruang yang belum ada pesaingnya. Dengan demikian perguruan tinggi di Indonesia akan tetap bertahan meskipun mendapat gempuran dari perguruan tinggi asing.

\section{Daftar Pustaka}

Ahn, Sanghoon, 2002, Competition, Innovation, and Productivity Growth: $A$ Review of Theory and Evidence, OECD Working Paper 20.

Baswir, Revrisond, 2003. Di Bawah Ancaman IMF, Yogyakarta:Pustaka Pelajar.

Birkler;J. 2001. Assessing Competitive Strategies for the Joint Strike Fighter: Opportunities and Options, Santa Monica,CA:Rand Corporation.

Chen, Cristine Y, 2002. The Wold's Most Admired Companies. March 11, Fortune.

Czinkota, Michael R.dan Ronkainen, Jlkka A. 2004. International Marketing, Sevent Edition, Thomson ShouthWestern

D'Aveni, Richard A. and Gunther, Robert. 1995. Hypercompetitive Rivalries: Competing in Highly Dynamic Environment. New York : Free Press

Flint, Joe. 2000. Commercial Clutter on TV Network Rises to Record, The Wail Street Journal, 2 Maret

George E. Belch, Michael A. Belch. 2004. Advertising and Promotion :An Integrated Marketing Communications Perspective, McGraw-Hill: Fourth Edition. 
Strategi Bersaing Perguruan Tinggi Menghadapi Liberalisasi Pendidikan; M.Suyanto

Gunther; Marc. 2002. The Future of Television, Fortune, 1 April

Hamel, Gary and Prahalad,C.K. 1994. Competing for the Future, Boston, Harvard Business School Press

Hamel, Gary. 1998. Opinion: Strategy Innovation and the Quest for Value, MIT Sloan Management Review 39, no. 2, 8.

$\mathrm{Kim}$, W. Chan, Mauborgne, Renee. 2005. Blue Ocean Strategy: How to Create Uncontested Market Space and Make the petition Imelevant,Boston: Harvard Business School Publishing Corporation.

Kotler, Philip and Amstrong, Gary. 2004. Principle of Marketing, Prentice-Hall

Michael E. Porter, 1985. Competitive Advantages. New York: Free Press.

Mittal, Banwari. 1994. Public Assesment of TV Advertising : Faint Praise and Harsh Criticism, Journal of Advertising Research Vol.34. No.1

Philip R. Cateora, John L. Graham. 2002. International Marketing, Eleventh Edition. McGraw-Hill

Robert Levering, Milton Moskowitz. 2002. The 100 Best Companies To Work For. March 11. Fortune
Ries, Al and Jack Trout. 1993. The $22 \mathrm{Im}$ mutable Laws of Marketing, New York, Harper Business.

Ries, Al dan Trout, Jack. 2001. Positioning : The Battle for Your Mind. McGrawHill.

Stern, Barbara B. 1994. Classical and Vignette Television Advertising: Structural Models, Formal Analysis and Consumer Effects, Journal of Consumer Research, Maret

Sloane, A. 1996. Multimedia Communication. McGraw-Hill Publishing.

Suyanto, M., 2003. Strategi Periklanan pada E-Commerce Perusahaan Top Dunia, Yogyakarta:Andi

Suyanto, M.. 2004. Aplikasi Desain Grafis Untuk Periklanan. Yogyakarta:Andi

Terence A. Shimp, 2000. Advertising and Promotion : Supplemental Aspects of Integrated Marketing Communications, Fifth Edition. The Dryden Press

Warren J. Keegan, Mark S. Green, 2003. Global Marketing, Third Edition, Printice-Hall. 